\title{
Uji Aktivitas Antioksidan Ekstrak Etanol Batang Daun Dan Bunga Jumpai (Glinus oppositifolius (L.) Aug. DC.)
}

\author{
Astuti Amin*, Andi Paluseri, Wahyu Hendrarti, Rahmat Priyandi Linggot \\ Sekolah Tinggi Ilmu Farmasi Makassar, Makassar, 90241, Indonesia
}

\begin{tabular}{l} 
I N F O A R T I K E L \\
\hline Diterima 27 Januri 2021 \\
Disetujui 30 April 2021 \\
\\
\hline Key word: \\
Antioxidants, \\
Jumpai (Glinus oppositifolius \\
(L.) Aug. DC.), \\
flavonoid, \\
DPPH (2,2-diphenyl-1- \\
picrilhydrazil) \\
\hline Kata kunci: \\
Antioksidan, \\
Jumpai (Glinus oppositifolius \\
(L.) Aug. DC.), \\
flavonoid, \\
DPPH(2,2-diphenyl-1- \\
picrilhydrazil). \\
\hline
\end{tabular}

email:amin.astuti@gmail.com

\begin{abstract}
A B S T R A C T
Jumpai Glinus oppositifolius (L.) Aug. DC is a plant that contains flavonoids which can act as antioxidants. This study aims to determine the antioxidant potential of the ethanol extract of stems, leaves and flowers by looking at the IC 50 value. The stems, leaves and flowers were extracted by maceration using $70 \%$ ethano solvent. The results of the antioxidant activity test using the DPPH method (2,2-diphenyl-1picrilhydrazil) showed very strong antioxidant activity with IC 50 values of $9.523 \mu \mathrm{g} /$ $\mathrm{ml}$ stem, $32.89 \mu \mathrm{g} / \mathrm{ml}$ leaves and $23.07 \mu \mathrm{g} / \mathrm{ml}$ flowers with positive control. vitamin C obtained IC 50 value of $1.698 \mu \mathrm{g} / \mathrm{ml}$. Based on these results, it can be concluded that the stems, leaves and flowers have antioxidant activity with a very strong category against DPPH free radicals (2,2-diphenyl-1-picrilhydrazil).
\end{abstract}

\section{Pendahuluan}

Antioksidan adalah senyawa pemberi elektron atau reduktan. Senyawa ini memiliki berat molekul kecil, tetapi mampu menghambat reaksi oksidasi, dengan cara mencegah terbentuknya radikal bebas jus [1]. Antioksidan alami bisa berasal dari buah-buahan dan tanaman sedangkan antioksidan buatan dihasilkan dari sintesis suatu reaksi kimia. Penggunaan antioksidan buatan cenderung memiliki negatif bagi kesehatan tubuh [2]. Saat antioksidan endogen (dalam tubuh) tidak dapat dipastikan mampu melindungi tubuh dari oksigen reaktif maka diperlukannya zat antioksidan eksogen (luar tubuh) seperti suplemen nutrisi atau produk farmasi, yang mengandung prinsip aktif senyawa antioksidan. Antioksidan eksogen yang paling sering di jumpai dari sumber alami seperti vitamin, flavonoid, antosianin, beberapa senyawa mineral [3]. Apabila kadar radikal bebas terlalu tinggi karena pengaruh dari luar tubuh seperti polusi udara, asap rokok, dan, aktivitas fisik berat, maka antioksidan dalam tubuh tidak mampu lagi menetralisir sehingga dibutuhkan antioksidan dari luar tubuh [4].

Tumbuhan memiliki metabolit sekunder yang dikenal akan fungsinya sebagai antioksidan adalah flavonoid. Flavonoid berperan sebagai antioksidan dengan cara mendonasikan atom hidrogennya atau melalui kemampuannya mengkhelat logam, dalam bentuk glukosida (mengandung rantai samping 
glukosa) atau dalam bentuk bebas yang disebut aglikon [5].

Berdasarkan penelitian yang dilakukan Sholekah menunjukkan bahwa kandungan fitokimia hasil dari metabolit sekunder seperti flavonoid berpotensi sebagai antioksidan [6]. Salah satu tanaman yang dipercaya mrngandung senyawa flavanoid yang berpotensi sebagai antioksidan adalah tanaman Jumpai (Glinus oppositifolius (L.) Aug. DC) [7].

Tanaman Glinus oppositifolius (L.) Aug. DC adalah tanaman yang tumbuh di Kota Sengkang, Kabupaten Wajo, Sulawesi Selatan. Tanaman Glinus oppositifolius (L.) Aug. DC sering dibuat sayur oleh masyarakat. Secara empiris tanaman Glinus oppositifolius (L.) ini juga dipercaya sebagai tanaman obat tradisional, analgetik, antidiabetes, antihiperlipidemik, antihelminthic, antidiarrhoeal, diuretik, antimalaria, antivirus, antimikroba dan antioksidan [8,9]. Selain itu di India Glinus oppositifolius (L.) Aug. DC telah digunakan secara tradisional sebagai obat sakit perut, stimulan uterus [10]. Tanaman Glinus oppositifolius (L.) Aug. DC banyak mengandung glikosida, flavanoid, fenol, steroid, saponin dan alkaloid. Senyawa flavanoid diduga sangat bermanfaat karena berupa senyawa fenolik dan bersifat antioksidan kuat [11].

Pengujian antioksidan dilakukan dengan menggunakan DPPH $\quad(2,2 \quad$ diphenyl-1picrylhydrazyl) sebagai radikal bebas yang stabil.. Berdasarkan uraian tersebut dilakukan penelitian untuk menentukan aktivitas antioksidan dari ekstrak etanol batang, daun dan bunga Glinus oppositifolius (L.) Aug. DC dengan menggunakan metode DPPH (2,2-diphenyl-1-picrylhydrazyl).

\section{Metode}

\section{Bahan dan Alat}

Alat yang digunakan antara lain aluminium foil, bejana maserasi, cawan porselen, kertas saring, rotary evaporator, spektrofotometer UV-Vis, timbangan analitik, water bath, dan gelas piala, labu ukur $10 \mathrm{ml}, 25 \mathrm{ml}, 50 \mathrm{ml}$ dan $100 \mathrm{ml}$, beaker gelas, erlenmeyer, vial, pipet mikro, pipet volume, pipet tetes, neraca analitik, sendok tanduk, dan batang pengaduk.

Bahan yang digunakan antara lain: ektrak etanol batang, daun dan bunga G. oppositifolius, etanol 70\%, methanol p.a, air suling, aluminium klorida (Merck, Germany), asam galat (Merck, Germany), asam sitrat (Merck, Germany), DPPH
(Sigma-Aldrich), etanol p.a (Merck, Germany), etanol $70 \%$, etil asetat (Merck, Germany), $\mathrm{FeCl}_{3}$ (Sigma-Aldrich), $\mathrm{HCl}$ pekat (Merck, Germany), Kuarsetin (Sigma-Aldrich), n-Heksan (Merck, Germany), $\mathrm{Na}_{2} \mathrm{CO}_{3} \quad 7,5 \%$ (Merck, Germany), natrium klorida (Sigma-Aldrich), serbuk $\mathrm{Mg}$ (Sigma-Aldrich), reagen Folin-Ciocalteau (Merck, Germany) dan TPTZ (Sigma-Aldrich).

\section{Pembuatan Ekstrak Batang, Daun dan Bunga Jumpai} (Glinus oppositifolius (L.) Aug. DC)

Simplisia yang sudah kering ditimbang dan dimasukan ke dalam tempat maserasi kemudian dimasukkan pelarut etanol $70 \%$ dengan perbandingan (1:10). Maserasi dilakukan selama 3 kali 24 jami sambil diaduk, kemudian disimpan ditempat yang tidak terkena sinar matahari langsung. Ekstrak yang diperoleh diuapkan dengan rotary evaporator hingga didapatkan ekstrak kental.

Pembuatan Sediaan Uji Ekstrak Batang, Daun dan Bunga jumpai (Glinus oppositifolius (L.) Aug. DC)

Pembuatan larutan sediaan uji ekstrak batang, Daun dan Bunga Glinus oppositifolius (L.) Aug. DC Ekstrak etanol batang, Daun dan Bunga G. oppositifolius dilarutkan dengan etanol p.a dengan konsentrasi1 $1000 \mathrm{ppm}$ dalam $100 \mathrm{ml}$ pelarut 100 mg ekstrak. Kemudian $1 \mathrm{ml}$ di pipet, diencerkan dengan etanol p.a dengan menggunakan labu ukur $10 \mathrm{ml}$ sehingga didapatkan konsentrasi 100 ppm sebagai larutan stock. Pembuatan berbagai seri konsentrasi dari larutan stock ekstrak etanol batang G. oppositifolius di buat seri konsentrasi 1ppm, 2 ppm, 4 ppm, $6 \mathrm{ppm}$ dan 8 ppm lalu diencerkan dengan etanol p.a pada masing-masing pada labu ukur $5 \mathrm{ml}$.

\section{Pembuatan larutan DPPH}

Ditimbang DPPH 0,01577 g, kemudian dilarutkan dengan etanol p.a dalam labu ukur $100 \mathrm{ml}$.

\section{Pembuatan larutan Standar Vitamin C}

Vitamin C dilmasukkan dalam etanol p.a dengan konsentrasi 1000 ppm dalam $100 \mathrm{ml}$ pelarut yang mengandung $100 \mathrm{mg}$ ekstrak diencerkan dengan etanol p.a dalam labu ukur dengan konsentrasi 10 ppm sebagai larutan stock. 
Pengukukuran serapan larutan blanko DPPH

Larutan DPPH dipipet sebanyak $1 \mathrm{ml}$ kedalam labu ukur $5 \mathrm{ml}$, ditambahkan etanol p.a. kemudian diukur absorbansinya pada panjang gelombang $515 \mathrm{~nm}$ dengan dengan Spektrofotometri Vis.

Pengukuran aktivitas radikal bebas DPPH ekstrak batang, Daun dan Batang G. oppositifolius.

Masing-masing konsentrasi ekstrak batang, Daun dan Bunga dipipet sebanyak $1 \mathrm{ml}$ larutan pereaksi DPPH dan dicukupkan volumenya sampai $5 \mathrm{ml}$ dengan etanol p.a dalam masingmasing labu ukur. Larutan dihomogenkan dan didiamkan selama 30 menit, kemudian diukur pada panjang gelombang $515 \mathrm{~nm}$ dengan spektrofotometri Vis.

Pengukuran aktivitas pengikatan DPPH dengan Vitamin C murni

Dipipet $1 \mathrm{ml}$ larutan vitamin C, ditambahkan $1 \mathrm{ml}$ larutan DPPH kemudian ditambahkan etanol p.a samapi volumenya $5 \mathrm{ml} \mathrm{n}$ dalam labu ukur. serapan diukur dengan spektrofotometri Vis dengan panjang gelombang $515 \mathrm{~nm}$.

\section{Pengolahan Data}

Data hasil analisis antioksidan ekstrak batang, daun dan bunga Jumpai dengan Besar persentase pengilatan radikal bebas DPPH dihitung berdasarkan persamaan 1 [12].

Aktivitas antioksidan $=\frac{(\text { Abs.BlankoAbs.Sampel })}{(\text { Abs.Blank }) \times 100 \%}$

\section{Hasil dan Pembahasan}

Hasil aktivitas antioksidan batang, daun dan bunga jumpai dilakukan dengan metode $\mathrm{DPPH}$ karena Senyawa antioksidan dapat bereaksi dengan radikal DPPH melalui mekanisme donasi atom hydrogen dan menyebabkan terjadinya perubahan warna DPPH dari ungu ke kuning yang diukur pada panjang gelombang 515-520 nm. Hasil pengukuran aktivitas antioksidan ekstrak etanol batang, daun dan bunga Glinus oppositifolius (L.) Aug. DC dan vitamin C dengan DPPH.

Sampel yang digunakan pada penelitian ini adalah batang, daun dan bunga Glinus oppositifolius (L.) Aug. DC yang di ektraksi dengan metode maserasi. Pada metode maserasi sampel dipotong kecil- kecil kemudian dikeringkan terlebih dahulu sehingga didapatkan luas permukaan sampel yang besar. Pelarut yang digunakan adalah pelarut etanol $70 \%$ karena konsentrasi pelarut etanol sangat berpengaruh nyata terhadap rendemen, total fenol, total flavonoid dan aktivitas penghambat radikal DPPH [4].

Dengan menggunakan pelarut etanol $70 \%$ bisa mengikat senyawa polar sehingga bisa menembus dinding sel dan masuk ke dalam rongga sel yang mengandung zat aktif. Selain itu berdasarkan penelitian yang dilakukan bahwa semua bagian tanaman yaitu akar, batang dan daun tanaman Glinus oppositifolius (L.) Aug. DC mengandung alkaloid, flavonoid, glikosida, saponin, sterol, tanin dan memiliki aktivitas antioksidan yang tinggi $[13,14]$. Ekstrak etanol memiliki aktivitas penghambatan DPPH tertinggi yaitu sebesar 70\%. Untuk memaksimalkan hasil ekstraksi maka dilakukan sebanyak 2 kali (remaserasi) dimana ampas dari ekstrak pertama dimaserasi kembali. Ekstrak etanol 70\% disaring dan diuapkan dengan rotarievaporator hingga diperoleh ekstrak kental. Selanjutnya ekstrak etanol batang,daun dan bunga Glinus oppositifolius (L.) Aug.DC diuji aktivitas antioksidannya dengan menggunakan metode DPPH (2,2-difenil-1-pikrihidrazil).

Pengujian masing-masing ekstrak dilakukan terhadap 5 konsentrasi yaitu ekstrak etanol batang G. oppositifolius 1 ppm, 2 ppm, 4 ppm, 6 ppm dan 8 ppm, ektrak etanol daun G. oppositifolius 15 ppm, 20 ppm, 25 ppm, 30 ppm dan 35 ppm dan ekstrak etanol bunga G. oppositifolius 10 ppm, 15 ppm, 20 ppm, 25 ppm dan 30 ppm, diukur dengan spektrofotometer UV- Vis pada panjang gelombang $520 \mathrm{~nm}$ dengan vitamin C sebagai kontrol positif. Hasil pengujian aktivitas antioksidan dapat dilihat pada gambar 1,2 , dan 3 .

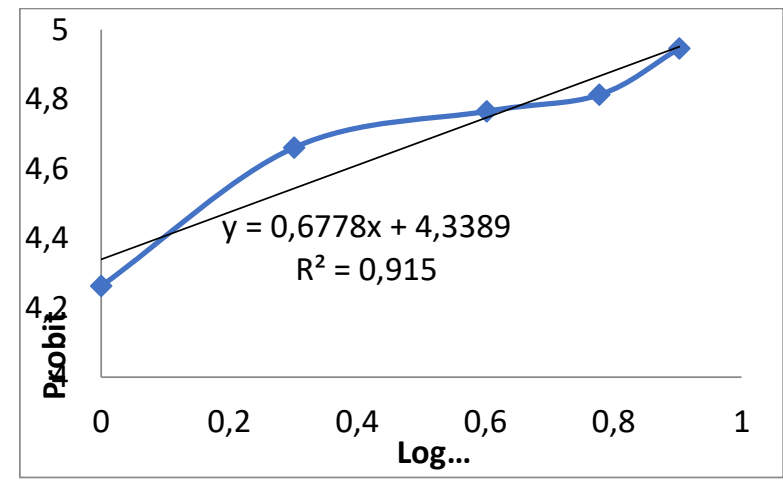

Gambar 1. Hubungan Log konsentrasi Ekstrak etanol batang Glinus oppositifolius (L.) Aug. DC dengan persen peredaman 


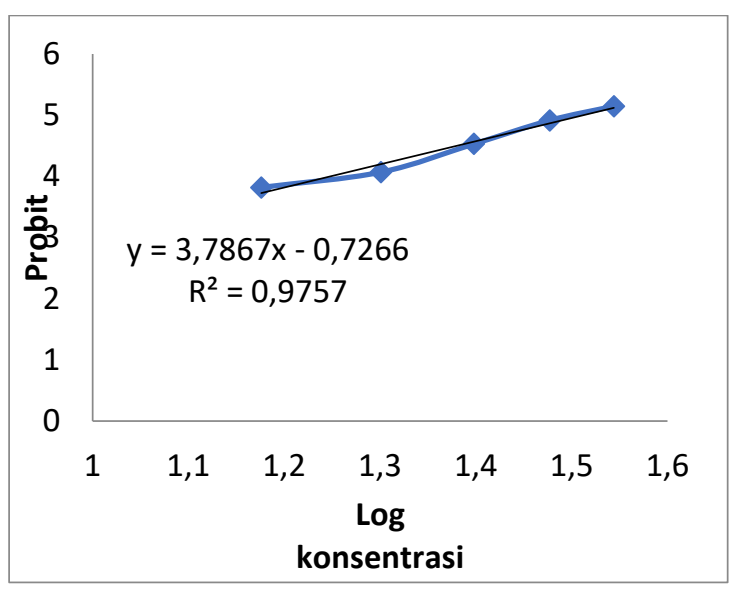

Gambar 2. Hubungan Log konsentrasi Ekstrak etanol Daun Glinus oppositifolius (L.) Aug. DC dengan persen peredaman

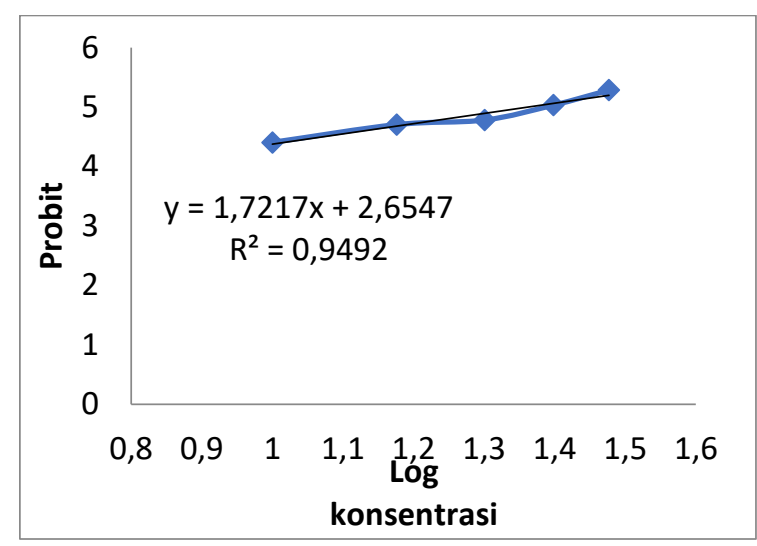

Gambar 3. Hubungan Log konsentrasi Ekstrak etanol Bunga Glinus oppositifolius (L.) Aug. DC dengan persen peredaman

Tabel 1. Nilai IC50 Aktivitas Antioksidan Ekstrak Etanol Batang, Daun, Bunga Glinus oppositifolius (L.) Aug. DC dan Vitamin C

\begin{tabular}{|c|c|c|c|c|c|c|}
\hline Sampel & $\begin{array}{l}\text { Konsentrasi } \\
\text { (ppm) }\end{array}$ & $\begin{array}{c}\text { Log } \\
\text { konsentrasi } \\
(\mathrm{X}) \\
\end{array}$ & $\begin{array}{l}\text { Inhibisi } \\
(\%)\end{array}$ & Probit (y) & $\begin{array}{l}\text { Persamaan } \\
\text { garis linear }\end{array}$ & $\begin{array}{c}\mathrm{IC}_{50} \\
(\mu \mathrm{g} / \mathrm{ml})\end{array}$ \\
\hline \multirow{5}{*}{$\begin{array}{c}\text { Ekstrak } \\
\text { etanol } \\
\text { batang G. } \\
\text { oppositifolius }\end{array}$} & 1 & 0 & 23,11 & 4,262 & $\mathrm{Y}=0,676 \mathrm{x}+$ & \multirow{5}{*}{$\begin{array}{c}9,523 \\
\mu \mathrm{g} / \mathrm{ml}\end{array}$} \\
\hline & 2 & 0,301 & 36,68 & 4,6604 & 4,339 & \\
\hline & 4 & 0,602 & 40,75 & 4,765 & $\mathrm{R} 2=0,915$ & \\
\hline & 6 & 0,778 & 42,62 & 4,8124 & & \\
\hline & 8 & 0,903 & 47,87 & 4,9461 & & \\
\hline \multirow{5}{*}{$\begin{array}{c}\begin{array}{c}\text { Ekstrak } \\
\text { etanol }\end{array} \\
\text { daun G. } \\
\text { oppositifolius }\end{array}$} & 15 & 1,176 & 12,98 & 3,819 & $\mathrm{Y}=3,786 \mathrm{x}-$ & \multirow{5}{*}{$\begin{array}{c}32,89 \\
\mu \mathrm{g} / \mathrm{ml}\end{array}$} \\
\hline & 20 & 1,301 & 17,62 & 4,0686 & 0,726 & \\
\hline & 25 & 1,398 & 32,01 & 4,5303 & $\mathrm{R} 2=0,975$ & \\
\hline & 30 & 1,477 & 46,74 & 4,9148 & & \\
\hline & 35 & 1,544 & 55,86 & 5,1472 & & \\
\hline \multirow{5}{*}{$\begin{array}{c}\text { Ekstrak } \\
\text { etanol } \\
\text { bunga G. } \\
\text { oppositifolius }\end{array}$} & 10 & 1 & 27,55 & 4,4065 & $\mathrm{Y}=1,721 \mathrm{x}+$ & \multirow{5}{*}{$\begin{array}{c}23,07 \\
\mu \mathrm{g} / \mathrm{ml}\end{array}$} \\
\hline & 15 & 1,176 & 38,3 & 4,705 & 2,654 & \\
\hline & 20 & 1,301 & 41,41 & 4,7823 & $\mathrm{R} 2=0,949$ & \\
\hline & 25 & 1,398 & 51,08 & 5,0316 & & \\
\hline & 30 & 1,477 & 61,13 & 5,2839 & & \\
\hline \multirow{5}{*}{ Vitamin C } & 0.4 & 0,398 & 9,70 & 3,702 & $\mathrm{Y}=2,232 \mathrm{x}+$ & \multirow{5}{*}{$\begin{array}{c}1,698 \\
\mu \mathrm{g} / \mathrm{ml}\end{array}$} \\
\hline & 0.8 & 0,097 & 19,72 & 4,1488 & 4,466 & \\
\hline & 1.2 & 0,079 & 30,58 & 4,4916 & $\mathrm{R} 2=0,918$ & \\
\hline & 1.6 & 0,204 & 41,82 & 4,7864 & & \\
\hline & 2 & 0,301 & 65,59 & 5,4018 & & \\
\hline
\end{tabular}

Berdasarkan analisis data menggunakan anilisis probit diperoleh nilai IC $_{50}$ dapat dilihat pada tabel 
1 dan gambar 1, 2, dan 3 . Hasil pengujian aktivitas antioksidan dengan metode DPPH didapatkan ekstrak etanol batang Glinus oppositifolius (L.) Aug. DC dengan nilai IC 50 sebesar 9,523 $\mu \mathrm{g} / \mathrm{ml}$, ekstrak etanol daun Glinus oppositifolius (L.) Aug. DC mempunyai nilai IC 50 sebesar $32,89 \mu \mathrm{g} / \mathrm{ml}$, ekstrak etanol bunga Glinus oppositifolius (L.) Aug. DC dengan nilai IC 50 23,07 $\mu \mathrm{g} / \mathrm{ml}$ dan vitamin $C$. Sebagai pembanding mempunyai nilai IC50 sebesar $1,698 \mu \mathrm{g} / \mathrm{ml}$. Semakin kecil nilai IC 50 berarti semakin kuat daya antioksidannya. Hal ini menunjukan bahwa daya antioksidan masingmasing ekstrak etanol daun, batang dan bunga G. oppositifolius memiliki aktivitas antioksidan yang sangat kuat dengan tingkat intensitas antioksidan dalam rentang nilai IC $5050-100 \mu \mathrm{g} / \mathrm{mL}$. Hal ini di sebabkan karena ekstrak etanol daun, batang dan bunga G. oppositifolius. memiliki Senyawa flavonoid dan senyawa fenolik. Dimana senyawa fenolik memiliki aktivitas antioksidan karena sifat reduksinya. Flavonoid dapat beraksi sebagai antioksidan dengan menangkap radikal bebas melalui pemberian atom hidrogen pada radikal tersebut. Secara umum, kemampuan flavonoid dalam menangkap radikal tergantung dari substitusi gugus hidroksi dan kemampuan stabilisasi dari radikal fenolik melalui ikatan hidrogen atau melalui delokalisasi elektron. Selanjutnya radikal fenoksi flavonoid tersebut distabilkan oleh delokalisasi elektron yang tidak berpasangan di sekitar cincin aromatik. Stabilitas radikal fenoksi flavonoid (reactive oxygen) akan mengurangi kecepatan perambatan (propagasi) autooksidasi reaksi berantai $[15,16]$. Sehingga dari hasil menunjukkan bahwa daya hambat antioksidan Vitamin $\mathrm{C}$ tetap lebih kuat dibandingkan dengan masing-masing ekstrak etanol daun, batang dan bunga G. oppositifolius. Hal ini disebabkan karena Vitamin C merupakan senyawa murni sedangkan ekstrak etanol batang, daun dan bunga masih merupakan ekstrak kasar bukan senyawa murni atau isolat. Sehingga nilai IC 50 Vitamin C lebi kuat dibandingkan dengan nilai ekstrak etanol Batang, Daun dan Bunga Glinus oppositifolius (L.) Aug. DC.

\section{Kesimpulan}

Dari hasil penelitian yang telah dilakukan pada ekstrak etanol Batang, Daun dan Bunga Glinus oppositifolius (L.) Aug. DC dapat disimpulkan bahwa ketiga ekstrak tersebut memiliki aktivitas antioksidan sangat kuat karena memiliki nilai $\mathrm{IC}_{50}<50 \mathrm{ppm}$ yaitu : ekstrak batang 9,523 ppm, ekstrak daun 32,89 ppm dan ekstrak bunga 23,07 ppm

\section{DaftarPustaka}

1. Jusmiati, J.; Rusli, R.; Rijai, L. Aktivitas Antioksidan Kulit Buah Kakao Masak Dan Kulit Buah Kako Muda. Jurnal Sains dan Kesehatan 2015, 1, 34-39.

2. Rahmi, H. Aktivitas Antioksidan Dari Berbagai Sumber Buah-Buahan Di Indonesia. Jurnal Agrotek Indonesia (Indonesian Journal of Agrotech) 2017, 2.

3. Aloanis, A.A.; Karundeng, M. Total Kandungan Antioksidan Ekstrak Etanol Buah Beringin (Ficus Benjamina Linn.). Fullerene Journal of Chemistry 2019, 4, 1-4.

4. Suhendra, C.P.; Widarta, I.W.R.; Wiadnyani, A.A.I.S. Pengaruh Konsentrasi Etanol Terhadap Aktivitas Antioksidan Ekstrak Rimpang Ilalang (Imperata Cylindrica (L) Beauv.) Pada Ekstraksi Menggunakan Gelombang Ultrasonik. Jurnal Ilmu dan Teknologi Pangan (ITEPA) 2019, 8, 27-35.

5. Sholekah, F.F. Perbedaan Ketinggian Tempat Terhadap Kandungan Flavonoid Dan Beta Karoten Buah Karika (Carica Pubescens) Daerah Dieng Wonosobo. In Proceedings of the Prosiding Seminar Nasional Pendidikan Biologi dan Biologi. Fakultas MIPA, Universitas Negeri Yogyakarta. Hal.: B75-B82; 2017.

6. Redha, A. Flavonoid: Struktur, Sifat Antioksidatif Dan Peranannya Dalam Sistem Biologis. 2013.

7. Inngjerdingen, K.T.; Patel, T.R.; Chen, X.; Kenne, L.; Allen, S.; Morris, G.A.; Harding, S.E.; Matsumoto, T.; Diallo, D.; Yamada, H. Immunological and Structural Properties of a Pectic Polymer from Glinus Oppositifolius. Glycobiology 2007, 17, 1299-1310.

8. Sheu, S.-Y.; Yao, C.-H.; Lei, Y.-C.; Kuo, T.-F. Recent Progress in Glinus Oppositifolius Research. Pharmaceutical biology 2014, 52, 1079 1084.

9. Traore, F.; Faure, R.; Ollivier, E.; Gasquet, M.; Azas, N.; Debrauwer, L.; Keita, A.; TimonDavid, P.; Balansard, G. Structure and Antiprotozoal Activity of Triterpenoid Saponins from Glinus Oppositifolius. Planta Medica 2000, 66, 368-371.

10. Suman Pattanayak; Subas Chandra Dinda; 
Siva Shankar; Durgaprasad Panda Antimicrobial and Anthelmintic Potetntial of Glinus Oppositifolius (Linn Family: Molluginaceae. Pharmacologyonline 2011, 1, 165-169.

11. Heinrich, M.; Barnes, J.; Gibbons, S.; Williamson, E.M. Farmakognosi Dan Fitoterapi. Jakarta: Penerbit Buku Kedokteran EGC 2009.

12. Aloanis, A.A. Analisis Pemerangkapan Radikal Bebas Ekstrak Etanol Buah Beringin (Ficus Benjamina Linn.). Fullerene Journal of Chemistry 2018, 3, 37-39.

13. Martin-Puzon, J.J.R.; Valle Jr, D.L.; Rivera, W.L. TLC Profiles and Antibacterial Activity of Glinus Oppositifolius L. Aug. DC.(Molluginaceae) Leaf and Stem Extracts against Bacterial Pathogens. Asian Pacific Journal of Tropical Disease 2015, 5, 569-574.

14. AsokKumar, K.; UmaMaheswari, M.; Sivashanmugam, A.T.; SubhadraDevi, V.; Subhashini, N.; Ravi, T.K. Free Radical Scavenging and Antioxidant Activities of Glinus Oppositifolius (Carpet Weed) Using Different in Vitro Assay Systems. Pharmaceutical Biology 2009, 47, 474-482.

15. Amin, A.; Wunas, J.; Anin, Y.M. Uji Aktivitas Antioksidan Ekstrak Etanol Klika Faloak (Sterculia Quadrifida R. Br) Dengan Metode DPPH (2, 2-Diphenyl-1-Picrylhydrazyl). Jurnal Fitofarmaka Indonesia 2015, 2, 111-114.

16. Hoque, N.; Imam, M.Z.; Akter, S.; Mazumder, M.E.H.; Hasan, S.R.; Ahmed, J.; Rana, M.S. Antioxidant and Antihyperglycemic Activities of Methanolic Extract of Glinus Oppositifolius Leaves. Journal of Applied Pharmaceutical Science 2011, 1, 5 .

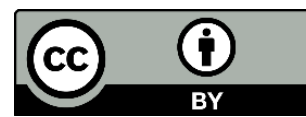

C 2021 by the authors. Licensee Fullerene Journal Of Chem. This article is an open access article distributed under the terms and conditions of the Creative Commons Attribution (CC BY) license (http://creativecommons.org/licenses/by/4.0/). 